\title{
Heteromated labour in 21st century computing capitalism: A critical
}

\section{conceptualisation of 'work'}

Zoe Adams - Junior Research Fellow in Law, King's College, University of Cambridge

Nicola Countouris - Professor of Labour Law and European Law, University College London

ILO RDW 2019 Conference, 9 July 2019

\section{Introduction.}

Ekbia and Nardi's conceptualisation of 'heteromation' as 'the extraction of economic value from low-cost or free 'labor 'in computer-mediated networks' ${ }^{1}$ offers a very powerful antidote to two major interrelated assumptions about the current processes of automation and digitalization of economic relations, and the effect of these processes on the concept of work. First, that human labour is systematically and irreversibly being displaced by processes of digital automation. ${ }^{2}$ The idea of heteromation challenges this assumption by boldly suggesting that automation is also accompanied by the emergence of 'heteromated labour in which the human operates on the margins of the machines ... While automated systems relieve humans of labour, heteromated systems demand it' ${ }^{3}$ Second, that human labour (but even the narrower concepts of 'work' or 'employment') is confined to traditional work environments, typically regulated by reference to the contractual, bilateral, and subordinate conception of the employment relationship, associated with the

\footnotetext{
${ }^{1} \mathrm{H}$. Ekbia and B. Nardi, Heteromation, and Other Stories of Computing and Capitalism (MIT Press, 2017), page 1.

2 add

${ }^{3}$ H. Ekbia and B. Nardi, Heteromation, and Other Stories of Computing and Capitalism (MIT Press, 2017), page 32.
} 
concept of the Standard Employment Relationship, and conventionally seen as the typical subject-matter of employment protection legislation. The idea of heteromation points us in the direction of capital and labour exchanges that lack one or more of the features conventionally associated with the concepts of 'work' or 'employment': they are not (or not self-evidently) contractually mediated and/or remunerated by wages; there is not always a clearly identifiable entity benefitting from that activity (a single employer, or consumer) with the person performing the activity appearing, under certain circumstances, as a 'user' seemingly benefitting from the activity itself; and the 'voluntary' and often seemingly psychagogical and 'enjoyable' character of the activities performed, which, in contrast to the more coercive or disciplinary nature of 'earlier' forms of work, tends to lend the labour a more innocuous appearance. ${ }^{4}$

Heteromation is not, according to the authors, an incidental process, but represents for all purposes a new mechanism 'for accumulating wealth', 5 an new process of capital accumulation premised on 'tiny moments of economically valuable labor that return very little to the worker but sustain wealthy, powerful companies'. ${ }^{6}$ As noted by Lianos and Ekbia in their paper presented in the present symposium, 'a great deal of value in the current economy is extracted outside of traditional work environments, where the dominant form of relationship between capital and labour is wage labour, including 'various forms of labour contributed by uncompensated labour of users of modern technology'. Their paper also powerfully points out how this process of accumulation has a distinct intercorporate dimension instantiating 'global value chains' relying on a ' novel economic environment with a new division of labour among firms, waged labour, gig workers, and end users'.

But Lianos and Ekbia also usefully point us towards the suggestion that not all value generated and extracted outside the traditional work environments through the intermediation of digital platforms can

\footnotetext{
${ }^{4}$ Ibid.

${ }^{5}$ Ekbia and Nardi, page 1.

6 Ibid. page 32.
} 
RDW 2019- Z. Adams and N. Countouris (Early Draft- Please Do Not Circulate)

compellingly be classified and understood as falling within the category of heteromated labour. Further refining and elaborating on the original work of Ekbia and Nardi, they, point out that 'a lot of value in the digital economy is extracted not from work, traditional or [alternative working arrangements], but from simple use, as digital platforms derive an important value from network effects, as use of a product or technology by any user increases the product's or technology's s value for other users (sometimes even all users), and therefore a large installed base of users is positively valued by financial markets'. And in part A of their paper they go on to propose a highly sophisticated analysis and distinction between various forms and configurations of 'heteromated work' as distinct, and distinguishable, from other varieties of 'heteromated use'.

In this paper, we seek to develop further the analysis and conceptualisation of the idea of 'work' in a capitalist economic system in general, and in $21^{\text {st }}$ century computing capitalism in particular. We will point out that, in a number of respects, the changes entailed by heteromation are not such as to change the fundamental nature of the labour performed. In other words, heteromated labour is still, by and large, 'work' in the capitalist sense: it is performed, sometimes by wage-dependent persons, sometimes for no remuneration at all, and often for some other form of consideration (or even no consideration at all), and contributes, in one way or another, to the overall process by which capital accumulation is sustained, and capitalism reproduced. It is, moreover, of concern to lawyers and policy-makers because it is labour that is, by definition, provided not for purely private benefit (and thus, personal consumption,) but for the benefit of others - whether an individual firm, a value chain, or capital/society in general. And this requires, moreover, as a fundamental condition of possibility, the receipt by those engaging in it, of a 'socially necessary wage'. 
In this paper, the term 'socially necessary wage ${ }^{77}$ refers to that bundle of rights and entitlements (including protections from physical and psychological harm), the receipt of which is necessary to ensure the productivity, health and wellbeing of workers (actual and potential) throughout the life course - and which is, by implication, necessary for sustaining the process of capital accumulation, and the process of social reproduction it presupposes. It includes, then, rights to monetary wages, but it also goes beyond this (including public services, state assistance, etc), and so, potentially engages not only labour law, but also aspects of tax, social security law etc.

\section{A broad concept of 'work' as 'abstract labour'.}

In the following pages, we set out to develop a conception of 'work' that isolates the distinctive, and essential features of labour in capitalism, and we do this through the lens of the Marxian concept of 'abstract labour ${ }^{8}{ }^{8}$ This, we argue, expresses the form that labour assumes in the context of capitalist social relations, labour that is performed by wage-dependent persons and which is, as a result, brought within the overall circuit by which capital is accumulated, and capitalist social relations reproduced. By developing a conception of work through this lens, we move beyond prevailing conceptions of work, or employment in the narrower sense, which tend to equate work with paid, contractual work (and, specifically, work performed under the direction and control of another), focusing instead on the broader function of the activity in the context of the capitalist system more generally. Far from representing a radical departure from existing approaches, however, we show that our conception of work actually bears many similarities with the notion of economic dependence that many labour lawyers have advocated as a focal point for reconceptualising labour law's personal scope. ${ }^{9}$ The key difference, however, being that, the emphasis is

\footnotetext{
7 TBA

8 TBA

9 See Freedland and Kountouris 2011; Rolling out the Manifesto for Labour Law, 2018. See also OECD Employment Outlook 2019, taking a sceptical view. To be clear, we do not refer to the concept of dependence as understood by those advocating economic dependence from a limited number of
} 
less on an individual's dependence on a particular firm or organization, and more on that individual's dependence on working for others in order to live.

The benefit of our broadened conception of work is two-fold. Firstly, it allows us to move away from a focus on inter-personal relationships between individual workers and firms, to explore the structural relationship between classes that gives rise to it. This allows us to move away from tests of employment status that focus either on the existence of a contract, and/or personal subordination/control, focusing instead on the social function of the work and the socio-economic status of the person performing it. Secondly, by allowing us to adopt a systemic, or structural perspective that focuses on the nature of the activity performed, we reveal the complex linkages that exist between different forms of 'work' in capitalism, and how they contribute to the functioning, and reproduction, of that system more generally.

Thus, as it will become apparent in the following pages, we recognise as 'work' not only those activities that contribute to the production of the surplus value appropriated by individual firms, but also/alternatively to the production of 'social' surplus value - the value available to capital in general, and to society, for the purposes of investment and for meeting social needs. This includes, for example, those (often) unpaid activities performed in wage-dependent households as an activity which, while not contributing directly to the profits of an individual firm, are nonetheless essential to the reproduction of labour power, and thus, capitalist social relations. It also includes those activities which, while not paid in practice, are performed for the benefit of an individual firm and/or society, by persons who could not perform such activities if they were not in receipt of a 'socially necessary wage' from somewhere. This allows us to encompass within our conception of work all those activities which require, as a fundamental condition of possibility, the receipt of a socially necessary wage, something which can only be guaranteed through law and institutions.

employers or principals as a test of quasi-subordination, e.g. as in the Spanish concept of TRADE, etc etc. 


\section{RDW 2019- Z. Adams and N. Countouris (Early Draft- Please Do Not Circulate)}

\section{Disentangling the concept of work from its normative implications.}

We do not, at this stage, draw direct normative/regulatory conclusions from our designation of a particular activity as 'work'. Rather, we emphasise the importance of separating the analytical question of what counts as 'work', and thus, who is a 'worker,' from the normative/legal consequences of such a designation when it comes to the design of legal rules and institutions. We have found that the traditional, and in many ways understandable, preoccupation that labour lawyers have for the substantive ratione materiae scope of their discipline has had a detrimental effect on the scope ratione personae of the notion of work. So, for example, one of the reasons (though not the only reasons) that has typically dissuaded most ${ }^{10}$ labour lawyers from conceptualising the domestic work typically performed by women in a household as 'work', has been a certain resistance to push the regulation of the relational and substantial aspects of 'domestic work' within the (narrow) confines of traditional employment protection legislation.

This reluctance to designate domestic work as amounting to proper 'work', as also noted by Lianos and Ekbia in their paper, owes 'a lot on the customs and social norms in a specific jurisdiction and broader societal considerations'. But we maintain, and go on to suggest, that much of it is also due to a resistance, sometimes at an unconscious level - to accept the normative and legal consequences of such a designation when it comes to the regulation of the relational aspects of domestic work. 'If a housewife is a worker, then who is the employer?'; 'should the husband pay wages?'; and 'can she claim unfair dismissal?' are some of the objections typically raised against any suggestion that domestic work may amount to work. These objections would seem to us as tantamount of putting the substantive cart before the conceptual horse, in a way that is neither productive nor necessary, as we go on to illustrate in section 7 below, by reference to a recent judgement of the CJEU on the employment status of foster parents'. ${ }^{11}$ Our alternative approach, and

\footnotetext{
10 Though not all - see Fredman and Fudge 2013, Fudge... TBA

11 C-147/17, Sindicatul Familia Constanţa and others v Direcţia Generală de Asistenţă Socială şi Protecţia Copilului Constanţa .
} 
RDW 2019- Z. Adams and N. Countouris (Early Draft- Please Do Not Circulate)

the underlying broader conception of 'work', would allow us to explore the various mechanisms conceptual and doctrinal - available to us when it comes to addressing the particular challenges that different types of work pose, and the different options that exist when it comes to securing a socially necessary wage in practice. This would be particularly useful when engaging with new forms of work and labour, including those springing from the highly original and novel idea of heteromation.

As with 'non-heteromated labour', each form of heteromated 'work' (whether work in the 'gig-economy', the user-generated data extracted by digital platforms, or customer work in the context of 'self-service' machines etc) necessarily generates practical, and regulatory challenges of its own, depending on its position, or role, in the overall process of capital accumulation, and on how it is integrated within capital's self-expansionary circuit. One of the particular challenges that must be addressed is how to identify those forms of 'work' the benefit of which is closed off to society as a result of its private appropriation by individual firms. In such circumstances, ensuring that the private beneficiary of that work bears a proportionate responsibility for securing the payment of a 'socially necessary wage' is particularly important - to avoid placing such costs on society and the state. Labour law, of course, but also (as noted by the paper by Berg, De Stefano, and Freedland) social security law, family law, tax law, and even competition and company law, will all be required, to ensure an appropriate regulation of heteromated labour, and thus, of the allocation of the costs and organization entailed in ensuring all 'workers' receive a socially necessary wage in practice. And, in fact, disentangling the conceptualisation of heteromated work from its normative implications allows us enough leeway to both recognise that it contributes to capital accumulation on a par with more traditional forms on non-heteromated labour, while at the same time recognising that its regulation should not be the exclusive business of labour legislation alone. 


\section{RDW 2019- Z. Adams and N. Countouris (Early Draft- Please Do Not Circulate)}

In making this argument, we also intend to fill a gap in prevailing debates about the future of work where the analytical question - what is 'work' - has rarely been addressed. ${ }^{12}$ Part of the problem, it seems to us, is that scholars tend to down-play the importance of conceptualisation, seeing it as an essentially passive exercise of 'fitting' new 'things' or 'practices' into appropriate conceptual boxes. For example, in debates about labour regulation, such as in the recent Taylor Review, it is implicitly assumed that there is a 'worker', 'employer' and 'self-employed' conceptual 'box', with the task being to decide which of these 'boxes' is the 'best fit' for the phenomena (or labour activity) in question. Not only does this risk obscuring the distinction between analytical categories, every-day language, and context-specific legal and/or economic concepts, it also tends to overlook the constitutive nature of the conceptualisation process itself.

Our view is that, while we might say that there are a number of conceptual boxes, corresponding with the words at our disposal, because the 'fit' between an entity (an Uber driver for example, or a particular form of 'labour') and any one box will be inherently imperfect, 'fitting' that entity in any box, will, necessarily, re-shape that box, and, by consequence, that which we have put into it. On this view, then, the 'classification' exercise is recognised to be a constitutive act: it not only changes the 'shape' of the object being classified, it also changes the meaning of the category/concept applied to it - and, as a result, has potential implications beyond the given case at hand. ${ }^{13}$ It is not, therefore, something to be undertaken lightly.

Not only is conceptualisation inherently constitutive; it is also path dependent. ${ }^{14}$ Novelty can only ever be responded to using existing structures; our conceptual resources are always confined to that which we already know. For this reason, (apparently) 'new' phenomena are always conceptualised by reference to

12 TBA

13 Zoe Adams, 'UNDERSTANDING THE MINIMUM WAGE: POLITICAL ECONOMY AND LEGAL FORM', The Cambridge Law Journal 78, no. 1 (March 2019): 42-69, https://doi.org/10.1017/S0008197318001009.

14 Mark Freedland, 'From the Contract of Employment to the Personal Work Nexus', Industrial Law Journal 35, no. 1 (1 March 2006): 1-29, https://doi.org/10.1093/indlaw/dwj001. 


\section{RDW 2019- Z. Adams and N. Countouris (Early Draft- Please Do Not Circulate)}

something past, and thus, the various ways those past things have been conceptualised historically. It is true, therefore, that much phenomena do not fit, precisely, within the scope of existing concepts and categories - hence the appearance of novelty. But it is also true that it is from those existing concepts and categories that new understandings, must be constructed. Proceeding by way of analogy is, then, inevitable - which is why it is so important to engage with the meanings embedded in the concepts (such as 'work') being used, to understand all that which it implies.

Our premise, then, is that how we describe, or conceptualise these 'new' forms of heteromated labour will influence the nature of those relations/practices as well as what we believe it is possible/impossible/necessary to 'do' with them - including, what is appropriate when it comes to questions of regulation. On the one hand, conceptualisation is inherently normative: to describe an activity as 'work' is to imply that it ought to be regulated in a similar manner to other forms of work, and so, (potentially) subject to (inter alia) labour law. This makes it particularly important to separate the analytical question is this, or that, 'work' - from the legal question - does this correspond with the legal conception of work as embodied in various legal concepts (such as 'worker', 'employee' etc)? On the other hand, however, conceptualisation is an act of constitution: by referring to an activity as work we change expectations and attitudes towards it, perceptions of worth, and value, and thus, potentially, the nature of the activity itself. We can thus decide, in other words, that, this activity is analogous to 'work' conventionally conceived, and so should be conceptualised, and regulated as such - and in this way, make a decision to influence how these practices themselves evolve.

It is on this basis that we defend the distinction we make between the analytical dimension of classification/conceptualisation, a process of conceptualising 'heteromated' labour by reference to our existing knowledge about forms of capitalist 'work'; and the normative/practical questions of what this implies vis-a-vis the rights/entitlements that might be required, and how our legal-conceptual and regulatory tools might be deployed to guarantee them. In addressing this more practical, legal, question, moreover, we 
need to take seriously that the legal categories through which capitalist work relations are denoted are not the same as the analytical categories employed to describe them, nor the (similar) terms used in every-day language. Rather, they have specific legal meanings, and implications, that depend to a great extent on how those work relations have been conceived, and regulated, in the past. We cannot just assume, therefore, that an activity that we designate as falling within the analytical category of work, and thus, an individual who we colloquially describe as working is, necessarily, someone that does, or ought, fall within, the personal scope of labour law and/or the framework of particular, pre-existing statutes and doctrines. Rather, this question must be addressed separately - and, for this reason, will be reserved for Part two of this article.

\section{Conceptualising capitalist 'work'}

In this paper, we draw a distinction between 'labour' - human activities that involve some form of mental, or physical exertion, but where the purpose of the activity is to produce something that can be consumed, and 'work.' The latter concept refers to the historically specific form that labour assumes in the context of the capitalist mode of production, something we refer to as 'abstract labour'. ${ }^{15}$

Labour only becomes 'abstract' in the context of the distinct social relation at the heart of capitalist society: the relationship between capital and labour. This relation arises from the exclusion of the direct producers from the means of production and subsistence, as that which produces their wage dependence, and their de facto compulsion to work on behalf of others (capital) in order to live. It is this wage dependence, procured by law and institutions, that brings individuals into a necessary relation with capital's expansionary circuit,

\footnotetext{
${ }^{15}$ The meaning of this term is contested. The term is interpreted in this paper broadly in line with the interpretation in: Moishe Postone and Louis Galambos, Time, Labor, and Social Domination: A Reinterpretation of Marx's Critical Theory (Cambridge University Press, 1995). See also: 'The Labour Debate: An Investigation into the Theory and Reality of Capitalist Work: Amazon.Co.Uk: Ana C. Dinerstein, Michael Neary: 9780754617792: Books', accessed 27 April 2019, https://www.amazon.co.uk/Labour-Debate-Investigation-Reality-Capitalist/dp/0754617793.
} 


\section{RDW 2019- Z. Adams and N. Countouris (Early Draft- Please Do Not Circulate)}

implicating them in the overall process by which capital accumulation is sustained, and capitalist social relations systematically reproduced.

Labour performed in a context of wage dependence (here understood as being dependent on the personal of personal, or mainly personal, labour-power in exchange for a wage) merits the designation 'abstract' because, in such circumstances, labour ceases to be (only) meaningful or fulfilling activity, where the nature of that activity, and its products, directly influences the needs and desires that can be met as a direct result of the labour performed. Instead, labour becomes a 'means' to something else - whether it be a means of gaining access to the labour market (as with the unpaid work of reproducing labour power in the home) or a means by which to obtain access to the products of the labour of others - through money (wages). Labour is 'abstract', then, in the sense that it becomes abstracted from its capacity to satisfy human needs (its qualitative dimension), and becomes, instead, something the purpose of which is primarily financial - to gain access to wages (its quantitative dimension).

Labour performed in conditions of wage dependence ('work') is thus labour that necessarily becomes incorporated into the circuit of capital, and its reproduction, as a result of the social relations in the context of which it exists. Incidentally, and to avoid any misunderstanding, this is as true for the unwaged work performed within wage-dependent households, reproducing labour power, as it is of the work of the individual 'employee' in the direct employ of an individual firm. It also includes those activities which, while not benefitting an individual firm or employer, are nonetheless essential to the process by which capital accumulation is sustained - and so benefits capital in general. This would include, for example, work in the public sector, (transport, law and order, etc), in social services, and even the various forms of 'free' or 'unpaid work' that very often contributes to the delivery of public services, and which individuals can only engage in because some agent has assumed responsibility for providing them with a 'socially necessary wage'. 


\section{RDW 2019- Z. Adams and N. Countouris (Early Draft- Please Do Not Circulate)}

Labour not performed in conditions of wage-dependence, labour performed by persons in ownership of the means of production, does not merit the designation 'work' therefore, for the labour of such persons is essentially concrete; and, by implication, is not incorporated into the overall circuit through which capital accumulation is sustained (even if it may be 'coloured' by the capitalist social relations with which it exists). This would include, for example, labour performed for exclusively for the purposes of private/personal consumption (other than in the context of a wage-dependent household) or by independent commodity producers with a view to personal gain. So for instance, leisurely allotmenteering or recreational physical exercise would not amount to labour as they are activities typically performed outside the parameters of wage dependence (that may not be the case if they are performed by members of wage-dependent households for the purposes of facilitating the reproduction of their own labour-power).

For the avoidance of confusion we should also point out that labour performed in conditions of wage dependence also includes work performed in a personal, or mainly personal, capacity by workers variably designated as self-employed, independent contractors, or autonomous professionals. Marx had already acutely pointed out that 'the self-employing worker is his own wage-labourer; his own means of production appear to him in his own mind as capital. As his own capitalist he puts himself to work as wage-labourer' ${ }^{16}$ Self-employed workers may even avail themselves of a modicum of capital to assist them with the performance of their personal work or service. But as long as they mainly rely on their personal work and service (and the use of capital is marginal or ancillary to that personal work) to earn their living, we are of the view, as stated elsewhere, that they perform their work in a context of dependence on wages (even though legal systems may refer to them as 'fees') and are therefore performing work. ${ }^{17}$

\footnotetext{
${ }_{16}^{16}$ K. Marx, Capital - Vol. 1 (Penguin 1982), page 1042.

17 Marx also noted that 'Such anomalies provide welcome opportunities for all sorts of hot air about the difference between productive and unproductive labour'. Ibid.
} 
The concept of 'work' includes, by contrast both the contractual, waged work of 'workers' and 'employees', and the various forms of 'unpaid' work that are performed by persons excluded from the means of production and subsistence, denied access to a 'socially necessary wage' in practice - persons whose labour capital appropriates, without regard for its costs of reproduction. In this respect, we might include not only forced labour (slavery, sex trafficking and child labour) but also those arrangements 'tricked out with a façade of legality' that involve the payment of less than socially necessary wages, and which is, today at least, often even encouraged, and faciliated by law: prison labour; labour in the context of immigration detention; debt bondage - and the various low paid service workers who, paid so little, are unable to support themselves by their wages.

\section{From 'work' to 'heteromation'}

The above analysis suggests that many of the features relied upon to distinguish heteromated labour from 'capitalist work' - the lack of a contract, of monetary remuneration, or a clearly identifiable 'employer' are not, in fact, distinguishing features of capitalist work - even if they have historically been important to the process by which they have been rendered socially and economically sustainable. Thus, what is 'new' about heteromated labour is not that it reflects a new form of capital accumulation and/or a new form of 'work.' Rather, it is the way that the integration of technology and machines makes the nature of the work, and its beneficiary, much harder to spot and, as a result, to conceptualise for the purposes of regulation, and when it to determining how, practically, to ensure that wage-dependent persons are in fact paid a socially necessary wage - that is, that their health, well-being and productivity is secured over time (something which, necessarily, depends on the (ever-evolving) customary standards of living prevalent in different places and at different times). 


\section{RDW 2019- Z. Adams and N. Countouris (Early Draft- Please Do Not Circulate)}

Before exploring the role for labour law in this context, two further points are worthy of note. The first is that, by separating the analytical question of what counts as 'work', from the question of 'who should be classed as a worker for the purposes of labour law' we open the door to recognising as 'workers' all those wage dependent persons brought within the circuit of capital accumulation - regardless of whether they provide 'paid' or 'contractual' work, and regardless of the particular context/s in which such work is, in fact, performed. We can, then, identify the individual as a 'worker', in the analytical sense, without drawing any legal, or practical conclusions from this for the purposes of labour/social security law.

The second point is that, having identified that individual as a worker (in the purely analytical sense), we know, at the outset, that she is someone to whom a socially necessary wage must be paid, if her activities, and the capitalist system more generally, is to be sustainable. The legal, or practical question is then how to use the legal-conceptual and doctrinal tools available to us to ensure that such a wage is in fact received, and that the burden for securing such a wage is distributed appropriately.

By 'socially necessary wage' it will be remembered, we are not referring exclusively to monetary wages: rather, we are referring to all that which a society (at a given time) deems necessary to secure workers' (and their dependents) productivity, health and well-being throughout their life course. It follows that such a 'wage' cannot, by definition, be the exclusive prevail of labour law - even if, in practice, labour law is likely to have a significant role to play. The labour power that such 'workers' provide to capital must be seen simultaneously as a communal resource that benefits society, and capital in general, and one that private firms will very often appropriate for private gain - limiting the benefit that is available to society as a whole. Hence, the key challenge will be to ensure that the immediate beneficiaries of a worker's work, where that beneficiary is a private firm/individual, effectively 'compensates' society for the benefit obtained. That is, they bear a proportionate costs of that worker's reproduction - of the socially necessary wage. 
In this respect, it is worthy of note that it has long been the case that forms of 'work' that benefit capital in general, (such as work in the public sector, and/or reproductive work in wage dependent households), has been funded not by individual firms, but by the tax-payer; while work the benefit of which is appropriated by private firms, has been funded by the firm itself (through wages, and employment law). This division makes sense, but it may be more difficult to draw in practice in the context of heteromated labour.

The data generated by users on social media platforms, for example, is not 'work' from which society can benefit - and yet, society must fund the reproduction of the labour power required to produce it because Facebook does not pay its users for their time. Thus, the availability of such 'work' is only possible because, and insofar as, individuals have access to alternative sources of subsistence that leave them with free 'time' to engage in the activities from which Facebook benefits. While it may be inappropriate/impractical to require Facebook to pay its users directly, therefore, it may nonetheless be appropriate to tax Facebook for its use of such data (funding public service/state assistance) and/or to require that it make that data available for public use. Similarly, to the extent that private firms benefit from the 'free' labour of consumers using self-service machines, saving them the costs involved in employing cashiers, it may be appropriate to require that any cost-saving obtained by such firms be passed on to the consumer in the form of lower prices - and/or to charge a license fee for the use of such machines, and to use the sums obtained for public purposes.

\section{Work, consumption and the heteromation paradigm.}

The previous two sections will have alerted the most careful reader about the risk of identifying a concept of work in general, and heteromated work in particular, that is so broad and lose as to potentially absorb areas of human activity that are traditionally not covered by labour law and also, and perhaps more strikingly, areas of human activity that are traditionally perceived as developing in the context of capitalist consumption (and to borrow the expression of Lianos and Ekbia, 'heteromated use'), rather than capitalist production. 


\section{RDW 2019- Z. Adams and N. Countouris (Early Draft- Please Do Not Circulate)}

Traditional Marxist theory has somewhat struggled to conceptualise the idea of consumption and to reconcile the role of workers as consumers. Marx himself developed his conceptual categories in a context where mass-production had not quite developed on the more discernible scale it would assume later, in the late $19^{\text {th }}$ century, and where mass-consumption the way we have come to understand it was probably unimaginable. It is beyond the scope of this paper to examine in detail the way Marx, and Marxists after him, have conceptualised consumption. But a brief account of Marx's work would arguably have to acknowledge that he correctly (for his time and in that context of capitalist economic and industrial development) identified very strong and consequential systemic links between the acts of consumption and the acts of production, which, as systemic features of capitalism, remain relevant today. They thus continue to shape consumption and use both in the context of automation and in the new emerging context of heteromation.

According to Mulchahy, 'In the purely technical terms of production of value, consumption is, for Marx, the moment that triggers reproduction when commodities as the objects of production are removed from the process of production and consumed by individuals' ${ }^{18}$ Put simply, Marx foresaw a system where workers contributed their personal labour which, when combined with the capital owned by the capitalist, created commodities consumed by workers thanks to the wages they received from him (that were always a fraction of the actual value their labour generated, the surplus being pocketed by the capitalist). At the same time, these acts of consumption necessarily create the need for further production, further demand for work, further extraction of value from their personal labour by squeezing wages, and further capital accumulation. Each act, then, contributes simultaneously to the reproduction of workers, and the necessity to work. Hence, as Mulcachy rightly notes, for Marx, this system was characterized by the 'fundamental ontological contradiction of the production of value, namely that, although capitalists seek the exchange-

\footnotetext{
$18 \mathrm{~N}$. Mulcahy, 'Workers-as-consumers: Rethinking the political economy of use-value and the reproduction of capital' (2017), Capital \& Class, p. 318.
} 
RDW 2019- Z. Adams and N. Countouris (Early Draft- Please Do Not Circulate)

value of commodities, a commodity is a use-value to a worker, who has to resort to exchange for his or her own existence'. 19

The essential features of this analysis were not fundamentally challenged by the rise of mass-production in the late $19^{\text {th }}$ century, and later, by the emergence of mass-consumption and consumerism. As massproduction reduced the unit cost of goods, workers could buy and consume more goods for the same or lower levels of wage, which in turn allowed capitalists to pocket a larger share of surplus value; if they were not investing it in advertising promoting consumption on new, more efficient, machinery, that is, further exacerbating the contradiction inherent in value production. If anything the work led by Mulchahy suggests that consumerism has further cemented the links between the status of an individual as a worker and the status of an individual as a consumer. She summarises her thoughts as follows: 'In short, consumption continues to be a moment when, as sellers of commodities, capitalists rely for their existence on workers-as-consumers to purchase goods and complete the circuit of production' ${ }^{20}$ Consumerism and advertising may have pushed the working classes into consuming commodities and using services that may not be, strictly speaking, necessary for the purposes of social reproduction, and that may - at the opposite end of the spectrum - be seen as luxury goods. But such goods and services has been marketed explicitly, as 'important to the working class because they provide some use, either through necessity or enjoyment, thereby improving quality of life in the personal sphere as a form of redress for the drudgery of work' ${ }^{21}$ And if 'consumption appears, then, as a form of compensation for work, it is hardly surprising that workers 'have been defined and celebrated $[\ldots]$ as consumers first and positively (and workers as secondary and negatively)', ${ }^{22}$ Mulcachy rightly claims. Citing the work of Ohman she concludes, persuasively in our view

\footnotetext{
19 lbid. 319.

20 Ibid. 322.

21 lbid. 


\section{RDW 2019- Z. Adams and N. Countouris (Early Draft- Please Do Not Circulate)}

'that 'it is an error to mark off consumption as a separate activity in the circuit of work, reproduction, and leisure. Better to see the use of commodities as a series of moments in the whole process' (p. 170). In spite of advancements in production techniques and product standardisation, which led to a drop in prices and the affordability of many commodities, in addition to increasingly sophisticated and pervasive forms of advertising, the working class still must consume to reproduce their labour-power, rather than because they have entirely fetishised commodities'. ${ }^{23}$

How does this strong link between work and consumption translate for the purposes of the newly emerging heteromation paradigm of capital accumulation identified by Ekbia and Nardi in their seminal 2017 monograph? We believe that it should assist with identifying at least two important analytical keys.

Firstly, one should approach with some caution any suggestion that, within the capitalist cycle of production, the status of worker is ontologically separate from the status of consumer or user. As the previous paragraphs suggest, this point was already arguable prior to the emergence of the idea of heteromation. But the work by Ekbia and Nardi must certainly encourage caution, even skepticism, in accepting clear boundaries between work and use, and would actually seem to point towards a further blurring, if not overall collapse of those boundaries and the categories they identify. Workers have traditionally also been consumers, and they have most certainly been 'users' of goods, services, and also of capital (in the form of machinery of equipment), that either belonged to their employer or that they may have had to contribute, on the margins, to be able to offer their labour. But if anything, one of the effects of technological developments has been to narrow the temporal separation between production, use, and consumption, making it difficult to distinguish, practically, the point at which a worker's 'productive' activity becomes, essentially, use or consumption. Thus, while Marxism perceives workers as a class on the premise that they are separated from the means of production and must therefore resort to exchanging

23 Ibid. 323-324. 
RDW 2019- Z. Adams and N. Countouris (Early Draft- Please Do Not Circulate)

their labour for a wage in order to make a living and to reproduce their labour power, heteromation points us to a world of digital capitalism where this separation is rendered more, not less, acute. This necessarily has consequences when it comes to how we conceptualise the 'subject-matter' of forms of legal regulation, such as labour law, given the need for a greater recognition of the work-consumption continuum.

Secondly, and this is a point that we explore further in following final section, 'heteromation' must also have normative implications in terms of a growing influence and regulatory reach of labour law in regulating both digitally mediated and heteromated human activities that contribute to capital accumulation. Especially so when such activities are provided for another or multiple entities allowing the latter to extract either surplus value (as canonically expected in capitalists systems of accumulation) and/or 'social' surplus value, as defined in section 3 above and more attuned, in our view, to the heteromated world of $21^{\text {st }}$ century computing capitalism.

\section{Heteromation, digital intermediation, and labour law}

Given our analysis above, we have shown that the labour provided by wage-dependent persons is, by definition, work, and that, where the benefits of such work is appropriated by a particular firm and/or organisation, this would seem to be something with which labour law should be concerned - for labour law is one of the principal, historically evolved, mechanisms through which 'socially necessary wages' has been secured.

Our conception of 'work' as 'abstract labour' - labour performed in conditions of wage-dependence, has the benefit that its bears a close resemblance to the idea of personal work or labour that a growing number of labour lawyers have advocated as a new focal point when it comes to reconceptualising labor law's 


\section{RDW 2019- Z. Adams and N. Countouris (Early Draft- Please Do Not Circulate)}

personal scope. ${ }^{24}$ The question, however, is how to use the conceptual and doctrinal tools available to us so that the courts might be able to identify such work in practice, and how to structure the regulatory framework so that it is adequately tailored to the nature, and context, of both (more) traditional or standard forms of work and digitally intermediated and 'heteromated' forms of work - in its various manifestations. This no doubt raises serious conceptual and practical challenges, as also highlighted by the latest 2019 OECD Employment Outlook, noting that 'An alternative approach which has been proposed is more radical, but would perhaps also encounter greater practical difficulties. The idea put forward is to no longer tie labour protections to employment status, but rather apply them to anyone performing work' ${ }^{25}$

Without seeking to offer a complete and exhaustive treatise of how our idea of work could inform the overhaul of the entire employment protection legislation edifice in the context of digital intermediation and heteromation, we venture to identify and engage with four key areas of regulation that are likely to require reform (and whose reform is likely to encounter greater difficulties, both conceptual and political). The first key question to address is, sans surprise, that of the personal scope of labour law, in order to identify how our idea of work translates into a functional and actionable concept and definition of worker. The second key question is, perhaps inevitably given our idea of work in general (and heteromated work in particular) as being personal work performed in ways that allow another entity to actually benefit from it by extracting and retaining a surplus value, is how to define the concept of employing entity or entities. A third area of regulation that will inevitably attract challenges and concerns is that of working time regulation, especially since, as Ekbia and Nardi remind us that 'looking ahead ... heteromated labor may be contributing to changing the employment relation and the nature of the economy to a system of tiny moments of economically valuable labor that return little to the worker but sustain wealthy, powerful companies'.${ }^{26}$ The fourth area is intimately related to the third, and pertains to the regulation of wages, in a context where

\footnotetext{
${ }^{24}$ Freedland Kountouris 2011; Countouris De Stefano 2019

25

${ }^{26}$ Ekbia and Nardi 2017, p. 32.
} 
'platforms' are optimally placed and capable of shifting excessive capital and regulatory costs onto workers (which they often consider independent entrepreneurs or users), depressing their take home pay below the minimum wage level .

\section{a. A broad worker definition.}

Defining the concept of 'worker' is a vexed question for a reason. 'Workers', unlike 'elephants' or 'ducks', do not exist in rerum natura (so we should probably agree that so called 'elephant tests' leave much to be desired here...). Their conceptualisation is an essentially political exercise as it performs an important redistributive function in the allocation of wealth, agency, and power (both individually and collectively) in capitalist societies. However, and as argued above, when applying concepts to 'new' contexts, we inevitably bring with us pre-existing assumptions and understandings, such that, it is never possible to 'start from scratch', so to speak. This means, essentially, that while we can advance an ideal definition, we remain highly dependent on the courts to interpret this definition in the spirit intended. This caveat notwithstanding, we are of the view that the primary goal of any worker definition should be that of reflecting and depicting the underlying concept of 'work' that it seeks to embody [We take an agnostic view as to whether this is how Parliaments and the courts actually go on about their task of elaborating and interpreting/developing their own particular worker or employee definitions]. So our concept of worker would need to consider the individual's broader position in the structure of capitalist social relations, and the relationship this creates between the individual's personal work, and the overall process of capital accumulation with which it is integrated. This definition could possibly be achieved by merely stating that a worker is ' $a$ person engaged by another to provide labour and is not genuinely operating a business on her or his own account' ${ }^{27}$ As noted elsewhere this would be a definition that would break free from the traditional straightjacket that is

${ }^{27}$ Rolling out the Manifesto 2018 
RDW 2019- Z. Adams and N. Countouris (Early Draft- Please Do Not Circulate)

the contract of subordinate employment and the shackles of contractuality, subordination, continuity, and bilaterality. ${ }^{28}$

There are three essential aspects to this definition. The first one if the concept of 'labour', which as noted above would equate with our idea of work (or 'abstract labour'). The second one is the aspect of the provision of labour 'for another' which, again as noted above, we understand as reflecting the process of acquisition and commodification of labour power for the processes of value extraction and capitalist accumulation. The term 'another' is broad and loose enough to embrace a range of employing entities, without excluding a priori either traditional employers, digital intermediaries, or other digital platforms. The third important dimension to that definition is the negative, exclusionary, of 'own account business'. The general idea here is that if a person is not solely or mainly earning a living from the performance of personal, or mainly personal, work but rather mainly from the use of either other people's work (typically his employees) or from a combination of small amounts of work that are marginal or ancillary to the ownership and organisation of capital that he controls, then that person should not fall within the worker definition.

We note that we already have existing, very broad, conceptions of worker that approximate our idea of work. A good example can be found in the UK definition of 'home worker' as contained in provisions such a s. 35(1) of the National Minimum Wage Act 1998. The definition departs from some of the traditional requirements sustaining the common law concept of contract of service for instance by expressly providing that work need not be provided in a strictly personal capacity, or within certain premises provided by the employer. Correctly, in our view, this broader definition has been interpreted generously in a way that would allow much of heteromated labour to be captured and classified as 'work'. According to Elias J, as he then was, in James $v$ Redcats (Brands) Ltd [2007] IRLR 296, 'it is not necessary that the home worker

${ }^{28}$ Countouris, Defining and regulating work relations for the future of work (ILO, 2019). 


\section{RDW 2019- Z. Adams and N. Countouris (Early Draft- Please Do Not Circulate)}

should personally carry out the work at all. It is the provision of services that is enough, irrespective of who provides them, as long as they are not provided in the course of running a business or profession'. This is because, 'frequently the work will involve, for example, making shoes or clothes, and that work is typically carried out by members of a family or a group of friends. (The growth of computer technology has also spawned many workers operating from home (so called "teleworkers") although they are more likely to do the work personally' (paragraph 7 of the EAT judgment).

There are good reasons for beginning to approximate the classificatory dilemmas posed by digitally mediated and hetoromated work by reference to the typically broader definitions that most employment law systems have retained to accommodate pre-modern forms of labour such as home-working. In recent work Acquier has offered the useful perspective that 'the emergence of platform capitalism should be understood as a digital reincarnation of the "putting out system," [...] a pre-industrial organizational form that preceded the emergence of manufacturing and the managerial corporation. In this system, merchants outsources work to individuals who produced goods at home and owned their own means of production' ${ }^{29}$ A fortiori it should be possible to rely on broader definitions of worker when these person at best own very modest amount of capital (in the form of a bicycle, a smart-phone, or a computer) and worst, and in reality, simply access and use of capital (for instance by leasing a $\operatorname{car}^{30}$ ) while mainly earning their living through the provision of personal, or mainly personal work, to another. This is a classificatory exercise that could of course greatly benefit from the inclusion of statutory presumptions, both general and specific. We note that even cautious judicial interpreters such as the Court of Justice of the EU are beginning to accept broader conceptions of work, for instance in cases such as Sindicatul Familia Constanţa where the Court did concede that 'foster parents ... must be regarded as 'workers' within the meaning of' the Working time

\footnotetext{
${ }^{29}$ A. Acquier, Uberization meets Organizational Theory, in Davidson, Finck, Infranca, The Law of the Sharing Economy (CUP, 2018), p. 14.

${ }^{30}$ Freedland and Kountouris, Some Reflections on the 'Personal Scope' of Collective Labour Law (2017) ILJ...
} 
Directive, while however resisting the conclusion that the right to paid holidays could be attributed to them. $^{31}$

b. A broad concept of employing entity and joint-employership.

In their joint paper Lianos and Ekbia correctly point out, by reference to the work of Schiek and Gideon, that it is possible to identify

'two main organisational models [...]: The first, 'epitomised by Uber, uses technology to match customers with persons delivering work in the real world, such as offering a ride (cab services), delivering items (courier services), caring for children, the elderly or pets, gardening, or other craft services"37. The second relies on the IT platform (through an app) to source work "from an anonymous group of "bidders", who are referred to as the crowd, hence the name crowd sourcing', where frequently the provider and the worker will not have direct contact as the process is organised through the IT platform38. These archetypes 'represent points on continuum"

To a certain - limited - extent this approach and classification, endorsed by a substantial number of studies, offers a reflection of the contemporary manifestations of two older and more established modes of labour intermediation, respectively those performed by employment agencies and those performed by employment intermediaries or businesses. But at a deeper level both models do much more than simply offer a modern, digital equivalent, of these more established and pre-digital manifestations. Both the model epitomized by Uber and the one epitomised by Task-Rabbit or Mechanical Turk, in reality tend to regulate extremely stringently the terms and conditions under which the workers' labour is appropriated by a variety of entities (all performing a certain amount of the functions typically associated with the unitary employer model) ${ }^{32}$

${ }^{31}$ Case C-147/17, para 48 and paras 74-88.

32 Jeremias Prassl, The Concept of the Employer (Oxford University Press, Oxford 2015) 
and also the way the surplus value that is extracted from that labour is to be distributed among them. In fact, we venture to suggest that these two characteristics are a common trait, a common denominator, of a variety of digital platforms relying on heteromated labour for the purposes of their operation and capital accumulation. They may do so in slightly less discernible ways than Uber or Amazon Turk do, but all platforms will typically ask their 'users' to relinquish a number of rights, including proprietary rights, in respect of the activities that they are asked or permitted to perform through the use of the digital technologies that they (and not the users) own.

With some minor exceptions, existing legislation offers very scant guidance to people working through intermediary entities and seeking to identify the real employer. A noteworthy exception is contained in s. 34 NMWA 1998 and reg. 36 WTR 1998, in respect of agency workers. Both provisions establish, in effect, a presumption of employer status for whichever entity 'is responsible for paying the agency worker in respect of the work; or [...] if neither the agent nor the principal is so responsible, whichever of them pays the agency worker in respect of the work'. Another broader formulation of the 'employer' concept can be derived, indirectly, from s. 43K(1)(a) ERA 1996, essentially positing that where a worker's terms of employment are 'in practice substantially determined ... by the person for whom he works or worked, by the third person or by both of them' then the worker may be considered as employed by whichever of the two entities played a greater role in setting those terms (and potentially by both of them if both have 'substantially determined' the terms of engagement and employment).

In recent years, section 43(1)(a) ERA 1996 has been generously and purposefully interpreted by UK Courts. In Day v Health Education England \& Ors [2017] EWCA Civ 329, a training doctor raised a series of concerns about the health and safety of his patients in a London hospital in connection with the inadequate, in his view, level of staffing in the acute care unit where he was performing his services. He claimed that, 


\section{RDW 2019- Z. Adams and N. Countouris (Early Draft- Please Do Not Circulate)}

as a consequence of raising his disclosures he was subject to a series of detrimental actions by both the hospital and in particular by the body providing the training and education regulatory framework for London doctors. It was clear to all parties that the relationship between the doctor and the training body (unlike that between the doctor and the hospital) was not regulated by a contract of employment. Thus the training body sought to avoid any liabilities simply by claiming that it was not acting as an employer, something that both the Employment Tribunal and EAT initially agreed with, and thus it could not have failed to protect the doctor as a whistleblower. But the Court of Appeal reversed the earlier decisions, effectively pointing out that the Tribunals were erroneously trying to identify who the real employer was by asking themselves which party, as between training body and the hospital, played the greater role in determining the terms on which the doctor was engaged, without envisaging the possibility that both could substantially determine the terms of engagement.

We believe that s. 43K(1)(a) ERA 1996, offers a reasonable and practicable way of resolving the 'who is the employer' question and it is arguable that this approach should be followed in the context of both digitally intermediated labour provisions and of heteromated work in respect of a wider range of labour rights, beyond whistleblowers' protection. The law defining the concept of employer could be reworded by presuming that the employer is the party that substantially determines the terms of engagement or employment of a worker, and that, in line with Day, where more than one party is so responsible (and regardless of whether one party is more responsible than the other, as long as both are 'substantially' responsible), the worker may address a claim against either or both putative employers. It is clear to us that in a world in which the functions traditionally performed by the unitary employer are increasingly fragmented and parceled out between different entities, doctrines such as the concept of joint employership and joint and several liability ought to play an increasingly important role in the identification of who is responsible for the employment rights workers are entitled to, giving workers and unions the opportunity to address their claims towards the entity with the deepest pockets or the one most conveniently located in the context of, often transnational, strategic litigation activities. 
c. Working time

The idea of 'work-on-demand' is neither new nor something labour law has not been tasked to regulate in the past. Already in the 1960s, Otto Kahn-Freund analysis of The Dock Workers (Regulation of Employment) Act, 1948 acutely analysed the ways in which a combination of legislative action and collective bargaining had both decasualised work relations among the endemically precariously employed dock workers and, at the same time, reshaped the conceptual boundaries of the contract of employment in English law. ${ }^{33}$ The emergence of the so-called gigeconomy seeks to push the concept of 'work-on-demand' to the limit, by fragmenting and parcelling working time in ways that artificially separate the concept of performance from that of remuneration. Heteromation provides an additional layer of complexity, by blurring the boundary between working time and user time.

It is clear to us that employers have always taken a narrow understanding of the concept of working time, seeking to minimise their liabilities in terms of pay obligations while maximising their access to readily available human labour. The CJEU case law on the concept of 'working time' has long exemplified the struggle of worker in the 'old economy' to resist the artificial fragmentation of the concept. ${ }^{34}$ The litigation surrounding the employment status of Uber drivers in the UK offers a very clear illustration of the possible complexities arising in this context. Throughout the dispute, Uber claimed that, should its drivers be reclassified as 'workers', then the company should

${ }^{33}$ O. Kahn-Freund, 'A Note on Status and Contract in British Labour Law' (1967) Modern Law Review, 642-643.

${ }^{34}$ C-14/04, Dellas ; C-266/14, Federación de Servicios Privados del sindicato Comisiones obreras $v$ Tyco. 
exclusively be liable towards them for the work provided 'during each ride, that is to say from the time the passenger is picked up until the time the car reaches the passenger's destination'. ${ }^{35}$ The drivers involved in the dispute counterclaimed that their worker status materialised from the very moment they switched on the app and declared themselves as available for work. ${ }^{36}$ In between these two claims, there was a third possible claim, whereby 'the driver is providing services to [Uber] from the moment he accepts the booking until the end of the passenger's journey but not when (in the words of [Uber]) he is simply circling around waiting for a call ${ }^{37}$ For the time being, English courts have appeared to favour the second, and more worker-protective, of these three options.

As the Employment Tribunal stated, the digital equivalent of the working day starts 'when the App in on'. This would seem to suggest that, conceptually, the idea of working time ought to be connected, at the very least, to the time workers spend operating the capital assets (material and immaterial) owned and controlled by the employer entity, or employer entities. A more purposive understanding of the concept of working time ought to include, as the CJEU might suggest, ${ }^{38}$ also those units of time where the worker is making herself 'available to the employer in order to be able to provide the appropriate services immediately [and] very significantly restricting the opportunities for other activities' ${ }^{39}$

\section{d. Minimum Wages}

35 Uber v Aslam [2018] EWCA Civ 2748, paragraph 100.

36 Ibid.

37 Ibid.

${ }^{38}$ Case C-518/15, Matzak

39 lbid. pars 59 and 66. 
Space precludes a detailed consideration of all issues relevant to the question of payment, but a number of core principles can be elaborated, based on the analysis of 'work' in part one. While proposals for a universal 'basic' income have proliferated in recent years, we believe that the notion of the 'socially necessary wage', and its emphasis on placing the costs of (re)producing labour power onto the firms and organizations benefiting from its exploitation, is to be preferred. Not only is such a key to a well-functioning or 'efficient' market, requiring firms to internalise their costs of production it is also essential for preserving the vital space for collective bargaining, and thus, the class struggle. A state provided basic income (and, to some extent, a system of wage supplements), removes from workers the capacity to fight for better terms and conditions. ${ }^{40}$ The answer to low pay, inequality and poverty, we believe, is not to find an alternative to the wage (not while society remains structured around 'work') but to explore how to better ensure the payment by firms to all workers of a form of living wage.

A core principle underpinning future models of wage regulation, then, must be the principle of a minimum guaranteed (daily, weekly or monthly) living 'wage,' payable to all those active in the labour market (all 'workers'), regardless of how much 'work' they actually perform on a given day, week, or month. This means shifting from the idea of a wage as a payment for a given quantum of work, to a conception of the 'living wage' as a basic right to which all workers ought be guaranteed. Not only does this mean decoupling the right to be paid from the amount of work provided, it means focusing less on what an employer pays, and more on what an individual worker actually receives, when all direct costs imposed on them as a result of their employment is taken into consideration.

\footnotetext{
40 See the insightful discussion of the UBI in: Pitts, F. H., \& Dinerstein, A. C. (2017). Postcapitalism, Basic Income and theEnd of Work: A Critique and Alternative. (Bath Papers in InternationalDevelopment and Wellbeing; Vol. 2017, No. 55)
} 
It seems to us that there are two key obstacles to operationalising this model in a context of heteromation. The first is that the tendency for firms to require their workers to provide their own capital (such as a car) means that, very often, even where a worker is paid a minimum wage, his take-home pay is much reduced. In relation to Uber drivers, for example, while they may be paid a minimum wage per 'trip', they are increasingly being subject to regulatory costs because it is they that provide their vehicles (congestion charges, insurance etc), forcing them to work longer hours just to make ends' meet. Thus, the guaranteed 'wage' must, we argue, be a wage that is guaranteed after all costs imposed on workers have been taken into consideration.

The second obstacle is linked with the casualization and fragmentation that heteromation often implies and, most specifically, the problem of 'multiple employers'. With the rise of digital platforms, and so-called cloud-work, many individuals today 'work' for multiple firms (or platforms) per week, and sometimes, per day - and they often do so on a one-off, or irregular, basis. As Lord Justice Underhill in Aslam v Uber has argued:

"There is no conceptual difficulty about a worker being in a contractual relationship with two employers during the same period; but I find it much more difficult to see how they could be said to be at the disposal of two employers, and carrying out duties for both, during the same period, or how the same period could be taken into account twice (or indeed more) for the purpose of calculating the national minimum wage obligations of different employers. The position would be still more extraordinary if drivers could bring into account time when they were actually driving on a trip obtained through a different platform." 41

${ }^{41}$ Aslam v Uber BV [2018] EWCA Civ 2748, at [162] 


\section{RDW 2019- Z. Adams and N. Countouris (Early Draft- Please Do Not Circulate)}

One solution to the problem, we suggest, is a system of centralised wage-payments. ${ }^{42}$ Employers seeking to purchase 'work' on a one-off or irregular basis would be required to contribute to a centralised wagefund, paying 'standard' wages in proportion to the work provided, and an additional levy on that sum, making up for any shortfall between the total 'wages' payable, and the guaranteed minimum. While such a system could operate at an industry, or sector, level (potentially involving the registration of all 'casual' workers and employers in a given industry or sector) a generalised model for 'casual', 'gig' or 'cloud' work is also conceivable. The premise would thus be that 'flexible' of casual work is permitted, but is subject to strict conditions. Such a system would respond to the challenge identified by Underhill J, preserving the advantages of flexibility, while reducing many of the associated 'costs'.

Our second core principle is that collective bargaining should once again become the primarily mechanism for setting wages. This would ensure that workers can actively participate in defining the 'living wage', while helping to tailor pay to the specific challenges faced by different groups of workers. While a statutory minimum would still have an important role to play - both as a benchmark for sectoral bargaining, and as a gap-filling mechanism where collective bargaining has failed, or broken down - we argue that the primary mechanism governing the setting of wages should be collective bargaining.

Finally, and as a logical consequence of the two principles outlined above, the role of state-provided wage supplements should be reduced, ending the subsidy on low pay, and placing power back in the hands of workers to fight for higher wages. Wage supplements have proven particularly ineffective for combatting poverty, while propping-up firms unable, or unwilling, to pay decent wages. ${ }^{43}$ Not only this, but their effect

\footnotetext{
42 Such a system operated in the UK dock industry from the 1940s - 70s and operated to 'decasualize' the docks, and guarantee all dockers a guaranteed wage, while ensuring port employers an adequate supply of labourers, notwithstanding rapid fluctuations in demand.

$4321 \%$ of employees (5.5 million people) were low paid in Great Britain in April 2014 and this proportion has changed little over 20 years: A Corlett, L Gardiner, Low Pay Britain 2015 (Resolution Foundation , 2015), at 18. Indeed, the controversy over wage supplementation can be traced back to the Speenhamland system of the $18^{\text {th }}$ century, an historical example that illustrates the danger of placing the burden on the state to cover workers' living costs, rather than relying on the mechanism of (and regulation of) the wage. '
} 
RDW 2019- Z. Adams and N. Countouris (Early Draft- Please Do Not Circulate)

is to shift the social costs of employment onto the tax-payer, and thus, by implication, onto workers themselves. As the primary exploiters of labour power, firms and organizations should bear the bulk of the responsibility when it comes to covering workers' living costs, and the requirement to do so should be a condition for their carrying on business and benefitting from the advantages associated therewith (favourable tax rules; limited liability etc) - for being allowed, in other words, to 'compete' in the market.

\section{Conclusion}

Ekbia and Nardi have highlighted just how many productive relationships, or modes of surplus labour extraction, operate outside prevailing conceptions of work or employment. In their paper, Lianos and Ekbia explored this idea in detail, contributing significantly to our understanding of the political economy of this process of 'heteromation'. As part of their analysis they suggested that a distinction should be drawn between heteromated 'labour' (or work) and heteromated 'use' - that some of these relationships are better seen not as acts of 'production' but as acts of 'consumption'. This observation prompted us to engage with their work and the analytical dichotomy prospected therein by developing a working conception of 'capitalist work', so that we might better understand the nature of the apparent 'changes' taking place.

In attempting this task, we elaborated a conception of 'work' through the lens of 'abstract labour.' This conception of work suggested that the essence of 'work' in capitalism is the performance of productive activities by wage-dependent persons, for it is this that brings that activity within the circuit of capital accumulation, and thus, the overall (social) process through which capitalist society is reproduced. Approaching the issue from this perspective, our analysis suggested that the distinction drawn by Lianos and Ekbia between 'work' and use' could perhaps also be seen in terms of a work-use (or productionconsumption/worker-/consumer) continuum: a circuit of activities through which wage-dependent 


\section{RDW 2019- Z. Adams and N. Countouris (Early Draft- Please Do Not Circulate)}

undertake activities that contribute in various ways to the reproduction of capital's expansionary circuit producing surplus value, and reproducing the labour power on which it depends. Seen in this light, the significance of 'heteromation' is not so much that it has changed the nature of work, or consumption; but that it has narrowed the temporal separation between the two, blurring, at the same time, the distinction between 'workers' in their capacity as a 'cost of production', and workers in their capacity as 'consumers'.

In the second part of the paper, we explored how this analysis of capitalist work might inform debates about labour law reform. While our suggestions in this respect were preliminary, we sought to articulate how labour law's existing conceptual and doctrinal resources might be used to respond to some of the challenges posed by heteromation. Greater sensitivity to the nature of work in capitalism, and of the importance, in that context, of the 'socially necessary wage', we showed, can provide an analytical key that can guide paths to reform. In particular, we advocated a broad conception of the 'worker', going beyond prevailing ideas of 'contractually' mediated work that is (straightforwardly) remunerated by wages, focusing on the socio-economic position of the individual providing 'personal labour' to a firm, or organization; a concept of the 'employing entity' that embraces ideas of joint employership and joint and several liability; a notion of working time that encompasses all time during which an individual is in control of the capital assets of the employing entity (including digital assets); and a system of minimum wage regulation based around the idea of a legally guaranteed (daily, weekly or monthly) 'living' wage.

Automation, digitally intermediated labour, and heteromation are here to stay. It is easy to foresee how, in the future, these dynamics may extended their influence over a growing number of sectors of the economy and of the so-called labour market. As Lianos and Nardi correctly point out, these developments are already facilitating the emergence of digital value chains across the globe as vehicles of value extraction from various groups of workers, while downplaying the important contribution of human labour to the growth of the digital capitalist enterprise. 
But markets, and labour markets, are also structured by rules, including of course those rules that shape the terms of the relationship between capital and labour. Labour law must lay its claim to the accumulation and redistributive questions arising from the technological and structural developments of $21^{\text {st }}$ century digital capitalist economies. As the other papers in this symposium go on to suggest, this claim can not be formulated in terms of exclusivity. Other legal disciplines and regulatory domains, from social security to family law, will undoubtedly want to contribute to this discourse. As the concept of work continues to expand beyond the more conventional understandings of employment on which labour law was founded in the $20^{\text {th }}$ century, there may be a certain degree of discomfort in abandoning the old categories and tools of the trade. But it is important to remember that labour law's redistributive vocation is deeply engrained and that, for instance, the 1944 ILO Declaration of Philadelphia already committed the Organisation to further programmes that would achieve 'policies in regard to wages and earnings, hours and other conditions of work calculated to ensure a just share of the fruits of progress to all, and a minimum living wage to all employed and in need of such protection'. This has to be an ongoing commitment, constantly attuned to the transformations affecting the world of production, consumption, and capital accumulation. And it therefore does not come as a surprise that the recently adopted ILO Centenary Declaration mandates the ILO to focus its efforts towards 'harnessing the fullest potential of technological progress and productivity growth, including through social dialogue, to achieve decent work and sustainable development, which ensure dignity, self-fulfilment and a just sharing of the benefits for all'. 